\title{
Siew New Disease Reports \\ First report of Cryphonectria parasitica on abandoned galls of Dryocosmus kuriphilus on sweet chestnut in the United Kingdom
}

\author{
A. Pérez-Sierra ${ }^{1 *}$, S. van der Linde ${ }^{1}$, P. Romón-Ochoa ${ }^{1}$, B. Jones ${ }^{2}$ and C. Gorton ${ }^{1}$ \\ ${ }^{1}$ Forest Research, Alice Holt Lodge, Farnham, Surrey GU10 4LH, England, UK ; ${ }^{2}$ Forestry Commission, 620 Bristol Business \\ Park, Bristol, England, UK
}

*E-mail: ana.perez-sierra@forestresearch.gov.uk

Received: 27 Apr 2020. Published: 10 Jun 2020. Keywords: chestnut blight, Castanea sativa, Oriental chestnut gall wasp

There are two quarantine pests affecting sweet chestnut (Castanea sativa) in the United Kingdom, chestnut blight caused by the fungus Cryphonectria parasitica and the Oriental chestnut gall wasp (OCGW), Dryocosmus kuriphilus. Chestnut blight is one of the most important diseases on chestnut and it was detected in planted orchards in England in 2011 (Hunter et al., 2013). The disease was eradicated and it was not detected again until 2016 when it was reported in the wider environment. Since then, it has been detected in woodlands, parks and street trees in different parts of England (Pérez-Sierra et al., 2019). The OCGW is one of the most important pests of Castanea species in the world and was detected in the UK for the first time in 2015 (Morath et al., 2015).

There have been reports in other countries in Europe indicating that the exit hole produced by the female wasp could potentially be an entry point for $C$. parasitica (Prospero \& Forster, 2011). Initially no OCGW was detected in chestnut blight-infected areas in England. However, during surveys for $C$. parasitica in 2018 and 2019, both insect and pathogen were detected on 26 sites in London and West Sussex. Twigs bearing abandoned galls of OCGW (Fig. 1) were collected to confirm the presence or absence of $C$. parasitica. Abandoned galls were initially surface disinfected with $70 \%$ ethanol, then cut open and the inner gall tissues, or tissue from the leading edge of the lesions (Fig. 2) selected for isolation and DNA extraction. Necrotic tissues were plated onto $2 \%$ malt extract agar amended with $0.25 \mathrm{~g} / \mathrm{l}$ of streptomycin sulphate salt. Plates were incubated for at least four days in the dark at $20^{\circ} \mathrm{C}$ and resulting colonies were transferred to PDA agar (39 $\mathrm{g} / \mathrm{l}$ potato dextrose) and incubated at $25^{\circ} \mathrm{C}$. DNA was extracted from gall tissues and from the isolated fungal colonies using the DNeasy Plant Pro DNA extraction kit (Qiagen, Germany) following the manufacturer's protocol. Up to $100 \mu \mathrm{g}$ of gall or fungal tissue was added to a tissue disruption tube. The samples were homogenised on a PowerLyzer24. A realtime PCR assay developed by Chandelier et al. (2019) was used to test for the presence of $C$. parasitica in each individual sample, using the 18Sspecific primers (Ioos et al., 2009) as an internal control. The real-time PCR was performed on a LightCycler 480 (Roche, Switzerland) system.

In total, 17 twigs containing several OCGW from five different infected sites were processed. Of those, ten tested positive for the presence of $C$. parasitica by real-time PCR and seven tested negative. The positives were detected from the five sites surveyed in London. Only in three cases was it possible to isolate $C$. parasitica from the galls in pure culture and they corresponded to three of the sites surveyed. In one of the samples the twig infested with OCGW galls showed a typical canker of $C$. parasitica.

To our knowledge, this is the first report of the colonisation of abandoned galls of OCGW by $C$. parasitica in United Kingdom. Further studies are

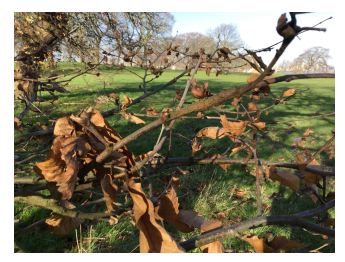

Figure 1

To cite this report: Pérez-Sierra $A$, van der Linde $S$, Romón-Ochoa $P$, Jones $B$, abandoned galls of Dryocosmus kuriphilus on sweet chestnut in the United Kingdom. New Disease Reports $41,34$. http://dx.doi.org/10.5197/j.2044-0588.2020.041.034 (C) 2020 The Authors

This report was published on-line at www.ndrs.org.uk where high quality versions of the figures can be found. needed to determine the interaction between the OCGW and C. parasitica and how this relates to the incidence of disease. Moreover, as the number of new sites which are co-infected/infested increases their interaction could imply a higher incidence of the disease in areas where both insect and pathogen occur.

\section{Acknowledgements}

The authors would like to thank Forest Research Tree Health Diagnostic and Advisory Service and Forestry Commission Tree Health teams for their assistance. The project was funded by the Department for Environment, Food and Rural Affairs (TH0157)

\section{References}

1. Chandelier A, Massot M, Fabreguettes O, Gischer F, Teng F, Robin C, 2018. Early detection of Cryphonectria parasitica by real-time PCR. European Journal of Plant Pathology 153, 29-46. http://dx.doi.org/10.1007/s10658-018-1538-0

2. Hunter GC, Wylder B, Jones B, Webber JF, 2013. First finding of Cryphonectria parasitica causing chestnut blight on Castanea sativa trees in England. New Disease Reports 27, 1. http://dx.doi.org/10.5197/j.2044-0588.2013.027.001

3. Ioos R, Fourrier C, Iancu G, Gordon TR, 2009. Sensitive detection of Fusarium circinatum in pine seed by combining an enrichment procedure with a real-time polymerase chain reaction using duallabeled probe chemistry. Phytopathology 99, 582-590. http://dx.doi.org/10.1094/PHYTO-99-5-0582

4. Morath S, Fielding N, Tilbury C, Jones B, 2015. Oriental chestnut gall wasp. News of a recent unwelcome discovery and how 'citizen science' can play an important role in surveying and identification. Quarterly Journal of Forestry 109, 253-258.

5. Pérez-Sierra A, Romón-Ochoa P, Gorton C, Lewis A, Rees H, Van Der Linde S, Webber J, 2019. High vegetative compatibility diversity of Cryphonectria parasitica infecting sweet chestnut (Castanea sativa) in Britain indicates multiple pathogen introductions. Plant Pathology 68, 727-737. http://dx.doi.org/10.1111/ppa.12981

6. Prospero S, Forster B, 2011. Chestnut gall wasp (Dryocosmus kuriphilus) infestations: new opportunities for the chestnut blight fungus Cryphonectria parasitica? New Disease Reports 23, 35. http://dx.doi.org/10.5197/j.2044-0588.2011.023.035

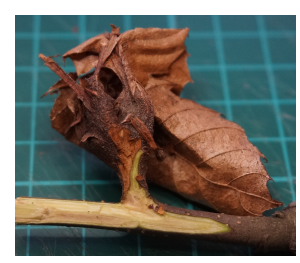

Figure 2 